\title{
PENGARUH PAJAK, KEPEMILIKAN ASING, BONUS PLAN DAN UKURAN PERUSAHAAN TERHADAP PERUSAHAAN MELAKUKAN TRANSFER PRICING (Studi Empiris pada Perusahaan Manufaktur yang Terdaftar di BEI Tahun 2014-2018)
}

\author{
Dyah Detari Prabaningrum ${ }^{1)}$, Titiek Puji Astuti ${ }^{2)}$, Yunus Harjito ${ }^{3)}$ \\ Fakultas Ekonomi/Program Studi Akuntansi, Universitas Setia Budi, Surakarta \\ 1)dyah18februari@gmail.com \\ 2) itiekpujiastuti@gmail.com \\ 3) yunus.harjito@gmail.com
}

Abstract : This study aims to test empirically the effect of taxes, foreign ownership, bonus plans and company size on transfer pricing in the manufacturing sector listed on the Indonesia Stock Exchange (BEI) for the 2014-2018 period. Based on the purposive sampling method, 33 companies met the criteria to be sampled in the study from 2014-2018. The number of samples in the study for 5 years with 165 observations. This study uses a panel data regression model. Based on the results of data analysis research, it can be concluded that taxes have a positive effect, while foreign ownership, bonus plans, and company size have no effect on transfer pricing in manufacturing companies listed on the Indonesia Stock Exchange in 2014-2018.

Keywords: transfer pricing, tax; foreign ownership, the bonus plan, the size of the company

\section{PENDAHULUAN}

Transfer pricing adalah kebijakan yang diterapkan perusahaan untuk menentukan harga transfer terhadap transaksi perusahaan baik dari barang atau jasa dilakukan dari suatu departemen perusahaan dengan cara ditransfer ke departemen lain dalam satu lingkup perusahaan atau perusahaan lain mempunyai hubungan istimewa (Yuniasih, 2012). Kasus transfer pricing atau harga transfer pada tahun 2018 meningkat cukup signifikan jika dibandingkan dengan tahun 2017. Dalam laporan 89 yurisdiksi menurut Mutual Agreement Procedure (MAP) Statistics pada tahun 2018, OECD menyebutkan bahwa sengketa transfer pricing di Indonesia naik hingga 20\%. Jumlah ini lebih tinggi jika dibandingkan pada tahun-tahun sebelumnya yang mencatat sebesar 10\%. OECD juga menambahkan bahwa mayoritas otoritas pajak menutup banyak kasus dibandingkan dengan kasus-kasus sebelumnya. Di sisi lain, data-data yang diperoleh dari pemerintah menunjukkan penurunan inventaris di sekitar setengah dari yurisdiksi pelaporan dan peningkatan di setengah lainnya.

OECD juga mempermasalahkan mengenai waktu sengketa transfer pricing. Rata-rata kasus transfer pricing di Indonesia meningkat jika dibandingkan dengan tahun 2017. Untuk penyelesain sengketanya, OECD melaporkan bahwa rata-rata penyelesaian pada kasus bervariasi mulai dari 2 hingga 66 bulan. Kasus penyelesaiannya $75 \%$ pada transfer pricing penyelesainnya dilakukan dengan kesepakatan perpajakan secara penuh atau sebagian tidak sesuai dengan perjanjian pajak sebesar 5\% akan diberikan keringanan sepihak dan 5\% diselesaikan secara domestic remedy. OECD juga menyebutkan bahwa statistik MAP tahun 2018 juga membandingkan pelaporan kinerja 
sehubungan waktu yang dibutuhkan untuk menutup kasus MAP dan jumlah kasus MAP yang ditutup untuk beban kasus yurisdiksi, untuk setiap jenis kasus. (Ekonomi bisnis, September 2019).

Di Indonesia terdapat perusahaan yang diduga melakukan transfer pricing yaitu PT Adaro Energy Tbk. Laporan yang dikeluarkan oleh Global Witness menyatakan bahwa dalam laporan tersebut perusahaan tambang besar di Indonesia yaitu PT Adaro Energy Tbk telah melakukan transfer pricing yang dilakukan tahun 2009 hingga 2017 melalui anak perusahaannya yang terdapat di Singapura Coaltrade Service Internasional. Adaro menggunakan strategi pembayaran pajak sebesar US\$ 125 juta atau setara Rp 1,75 triliun (kurs Rp 14.000) yaitu lebih rendah dengan pajak dibayarkan kepada Pemerintah Indonesia. Global Witness menyatakan laporan mengenai Adaro Energy melakukan pengalihan pendapatan ke anak perusahaannya yang berada di luar negeri. Tujuannya adalah untuk menghindari beban pajak. Adaro Energy diduga menjual batu bara ke coaltrade service internasional dengan harga yang jauh lebih murah. Kemudian batu bara tersebut dijual Kembali ke negara lain dengan harga yang lebih tinggi untuk memperoleh keuntungan yang tinggi tetapi dengan beban pajak yang kecil. Mengakibatkan penghasilan yang dikenakan pajak di Indonesia lebih rendah dari yang seharusnya dibayarkan (Thomas, 2019).

Penetapan prinsip kewajaran berdasarkan dokumen lain dan metode penentuan prinsip kewajaran yang dinilai tepat oleh Dirjen Pajak sesuai dengan pasal 13 ayat (1) Udang-Undang KUP (Ketentuan Umum dan Tata Cara Perpajakan) melalui pemeriksaan pajak. Apabila wajib pajak telah memenuhi prinsip kewajaran dalam setiap transaksi yang dilakukan dengan pihak yang memiliki hubungan istimewa. Demikian juga dalam hal terdapat indikasi sebagai tindak pidana dibidang perpajakan atas adanya transaksi yang memiliki hubungan istimewa maka Dijen Pajak berwenang melakukan penyidikan sebagimana diatur dalam pasal 44 Undang-Undang KUP (Ketentuan Umum dan Tata Cara Perpajakan) (Lamria, 2012).

Beberapa penelitian telah dilakukan oleh peneliti sebelumnya namun masih terdapat beberapa perbedaan terhadap hasilnya. Hasil penelitian yang dilakukan oleh Refgia (2017), Saraswati \& Sujana (2017), dan Tiwa et al. (2017) menyatakan bahwa pajak berpengaruh terhadap keputusan transfer pricing. Sebaliknya penelitian yang dilakukan oleh Marfuah \& Azizah (2014) dan Rosa et al. (2017) menyatakan bahwa pajak berpengaruh negatif terhadap keputusan perusahaan melakukan transfer pricing. Sedangkan penelitian Mispiyanti (2015) menyatakan bahwa pajak tidak berpengaruh terhadap keputusan perusahaan untuk melakukan transfer pricing.

Penelitian mengenai kepemilikan asing yang dilakukan oleh Kiswanto (2014) dan Refgia (2017) menyatakan bahwa kepemilikan asing mempunyai hubungan positif terhadap perusahaan melakukan transfer pricing. Dikarenakan apabila pihak asing menanamkan modalnya pada perusahaan publik di Indonesia maka pihak asing bisa memberikan pengaruh keputusaan perusahaan untuk melakukan transfer pricing. Penelitian yang dilakukan oleh Tiwa et al. (2017) dan Nurjanah et al. (2015) menyatakan bahwa kepemilikan asing tidak berpengaruh terhadap keputusan transfer pricing.

Penelitian yang dilakukan oleh Hartati dan Azlina (2014) dan Nurjanah (2015) yang menyatakan bonus plan berpengaruh terhadap transfer pricing. Sebaliknya, penelitian yang dilakukan oleh Mispiyanti (2015), Pramana (2014), Rosa et al. (2017), Refgia (2017), Saraswati dan Sujana (2017) yang menemukan bahwa bonus plan tidak berpengaruh terhadap hubungan transfer pricing. Bonus plan adalah dengan berdasarkan laba sering digunakan oleh perusahaan dalam memberikan penghargaan atas kinerja kepada para direksi. Adanya tingkat laba direksi atau manajer sehingga melakukan memanipulasi laba untuk memaksimalkan penerimaan terhadap bonus. 
Penelitian yang dilakukan Taylor (2013) menyatakan bahwa ukuran perusahaan berpengaruh terhadap keputusan perusahaan melakukan transfer pricing dikarenakan semakin besar perusahaan bisa dipastiakan transaksi yang terjadi semakin kompleks dan semakin besar perusahaan pasti memiliki sumber daya manusia yang kompeten untuk eminimalkan beban pajak perusahaan. Disisi lain penelitian yang dilakukan Akbar (2015) dan Refgia (2017) menunjukan bahwa ukuran perusahaan tidak berpengaruh terhadap keputusan perusahaan melakukan transfer pricing.

\section{Perumusan Masalah}

Berdasarkan latar belakang yang telah dijelaskan, penulis tertarik untuk melakukan penelitian dengan berfokus kepada " Bagaimana Pengaruh Pajak, Kepemilikan Asing, Bonus Plan, dan Ukuran Perusahaan terhadap Perusahaan Manufaktur yang terdaftar di Bursa Efek Indonesia pada tahun 2014-2018”.

\section{Tinjauan Pustaka}

\section{Teori Agensi (Agency Theory)}

Penelitian ini menggunakan teori agensi (agency theory). Teori keagenan memaparkan mengenai adanya hubungan antara pihak manajemen (agen) dengan investor (prinsipal). Hubungan antara pihak agen (agency relationship) pihak (prinsipal) yang memerintahkan orang lain (agen) untuk membuat keputusan yang terbaik bagi prinsipal. Pihak prinsipal mengkoreksi adanya perbedaan kepentingannya dengan memberikan insentif yang sesuai atas kinerjanya kepada agen dan bersedia mengeluarkan biaya pengawasan untuk mencegah kecurangan dari agen (Jensen dan Meckling 1976).

Hubungan yang timbul dari teori agensi dengan transfer pricing adalah mengenai asumsi sifat manusia bahwa setiap individu cenderung memikirkan kepentingan pribadinya sehingga timbulnya masalah keagenan karena terdapat pihak yang memiliki perbedaan kepentingan tetapi saling bekerja sama dalam pembagian tugas yang berbeda. Kewenangan juga berkaitan dalam pengelolaan aktiva perusahaan yang diberikan oleh principal kepada agen untuk mengenyampingkan kepentingan dari pemegang saham dengan memanfaatkan insentifnya untuk melakukan transfer pricing dengan tujuan untuk menurunkan pajak yang harus dibayar oleh perusahaan. Dengan adanya teori agensi diharapkan masalah berkaitan perbedaan kepentingan antara principal dan agen dapat berkurang dan diperlukan suatu pengendalian yang tepat untuk mengatasi perbedaan kepentingan yang terjadi antara principal dan agen (Hartanti dan Julita, 2015).

\section{Teori Biaya Politik (Political Cost Theory)}

Teori biaya politik adalah teori menjelaskan bahwa apabila semakin besar biaya politik yang ditanggung oleh perusahaan, maka semakin besar pula manager untuk memilih metode atau prosedur akuntansi yang dapat menurunkan laba yang dilaporkan saat ini guna untuk menekan beban pajak perusahaan. Dikarenakan dengan laba yang tinggi, pemerintah akan menaikkan pajak pendapatan perusahaan yang harus dibayarkan. Perusahaan yang berukuran besar akan memilih prosedur akuntansi yang dapat mengurangi laba yang dilaporkan. (Kharisma, 2014).

Hubungan teori biaya politik dengan transfer pricing adalah perusahaan besar akan menggunakan standar kinerja yang tinggi terutama perusahaan yang memiliki profit yang tinggi akan memperbesar adanya praktek biaya politik digunakan. Persaingan luar negeri mungkin dapat menurunkan profit perusahaan terkecuali bagi perusahaan yang terkena dampaknya ini bisa mempengaruhi proses politik pada suatu negara. Selain itu, bisa disebabkan adanya tekanan sosial 
terutama dari pemerintah yang menuntut perusahaan untuk membayar pajak kepada negara secara tidak langsung akan membuat perusahaan untuk melakukan transfer pricing guna meminimalkan pajak yang dibayarkan kepada pemerintah. Perusahaan menggunakan cara dengan mengalihkan kewajiban pajak perusahaan ke perusahaan relasinya yang berada di negara yang memiliki tarif pajak lebih rendah (Dynaty et al. 2011).

\section{Pengembangan Hipotesis}

\section{Pengaruh Pajak Terhadap Transfer Pricing}

Perusahaan harus menggunakan prinsip kewajaran dalam setiap transaksinya tetapi nyatany perusahaan melakukan transfer pricing digunakan untuk meminimalkan kewajiban perpajakan dari perusahaan agar beban pajaknya lebih kecil dari yang seharusnya. Menurut Yuniasih et al. (2012) apabila beban pajak semakin tinggi akan mempengaruhi keputusan suatu perusahaan untuk melakukan praktik transfer pricing dengan harapan jumlah pengenaan beban pajak dapat lebih kecil. Perusahaan yang memiliki anak perusahaan yang berada di negara yang memiliki tarif pajak tinggi maka akan memperoleh keuntungan yang lebih sedikit karena bebna pajak yang tinggi. Sebaliknya jika, anak perusahaan tersebut di negara yang memiliki tarif pajak rendah tentu saja akan memperoleh keuntungan yang lebih tinggi karena beban pajak yang lebih sedikit. Itulah yang menjadi strategi banyak perusahaan multinasional memiliki anak perusahaan yang berada di negara yang memiliki tarif pajak rendah (Nurjanah et al. 2015).

H1 : Pajak berpengaruh positif terhadap Transfer Pricing.

\section{Pengaruh Kepemilikan Asing Terhadap Transfer Pricing}

Pemegang saham yang dimiliki pengendali oleh asing memiliki pengaruh dalam pengambilan sebuah keputusan perusahaan seperti menjual produk dari perusahaan ke perusahaan milik pribadinya dengan harga di bawah pasar untuk memaksimalkan keuntungan yang akan diperolehnya. Pemegang saham pengendali oleh asing akan memperoleh keuntungan atas penjualan tersebut sedangakan akan merugikan bagi pemegang saham non pengendali (Kiswanto et al, 2013). Saham yang dimiliki oleh pengendali asing semakin besar maka pemegang saham pengendali asing memiliki pengaruh yang semakin besar dalam menentukan berbagai keputusan yang akan diambil di dalam perusahaan termasuk dalam menentukan kebijakan-kebijakan harga maupun jumlah transaksi transfer pricing oleh perusahaan.

H2 : Kepemilikan Asing berpengaruh positif terhadap Transfer Pricing.

\section{Pengaruh Bonus Plan Terhadap Transfer Pricing}

Para direksi dalam menjalankan tugasnya selalu ingin menunjukkan kinerja yang baik kepada pemilik perusahaan. Dengan dapat menunjukkan kinerja yang baik yaitu sesuai dengan tujuan yang ingin dicapai oleh perusahaan maka para direksi memperoleh penilaian yang baik dari pemilik perusahaan maka akan memberikan penghargaan kepada para direksi. Mispiyanti (2015) menyatakan bahwa bonus plan adalah satu strategi atau motif perusahaan dengan menggunakan perhitungan akuntansi yang tujuannya untuk memberikan penghargaan kepada direksi atau manajemen dengan melihat laba secara keseluruhan selama tahun berjalan.

Selanjutnya, praktik akuntansi akan berfokus pada angka akuntansi menjadi pedoman yang dibuat oleh para direksi supaya kinerjanya baik, sehingga akuntabilitas akuntansi dikesampingkan, maka praktik transfer pricing yang ilegal dalam akuntansi menjadi hal yang wajar. (Mispiyanti, 2015). 
H3 : Bonus plan berpengaruh positif terhadap transfer pricing.

\section{Pengaruh Ukuran Perusahaan Terhadap Transfer Pricing}

Ukuran perusahaan adalah menunjukkan besar atau kecilnya suatu perusahaan. Perusahaan yang memiliki jumlah aset yang besar menunjukkan bahwa perusahaan tersebut telah mencapai tahap kedewasaan yang dapat dilihat dari segi usia yangman arus kas perusahaan sudah bersifat positif dan dapat dianggap memiliki prospek baik dalam jangka waktu beberapa tahun kedepan. Ukuran perusahaan menjadi dasar investor dalam menanamkan modalnya karena akan berhubungan dengan resiko investasi yang dilakukan oleh para calon investor tersebut (Pujiningsih, 2011). Apabila semakin besar ukuran suatu perusahaan akan memiliki dorongan oleh para direksi untuk mengelola perusahaan tersebut menjadi lebih baik dengan cara melakukan pengelolaan laba, seperti halnya menggunakan praktik transfer pricing. Dikarenakan perusahaan besar memiliki laba lebih stabil atau meningkat dalam kurun waktu tertentu ini akan sangat berguna untuk menarik calon investor untuk menanamkan modal saham atau memberikan jaminan kreditur untuk memberikan pinjaman (Kiswanto et al, 2014).

H4: Ukuran perusahaan berpengaruh positif terhadap transfer pricing.

\section{METODE PENELITIAN}

\section{Populasi}

Populasi merupakan objek atau subjek yang digunakan sebuah penelitian yang mempunyai kualitas dan karakteristik tertentu untuk dipelajari dan kemudian ditarik kesimpulan guna penelitian selanjutnya (Sugiyono, 2011). Populasi yang terdapat dalam suatu penelitian ini adalah seluruh perusahaan manufaktur yang menerbitkan laporan keungan yang telah diaudit dan dipublikasikan di Bursa Efek Indonesia (BEI) pada tahun 2014-2018 secara berturu-turut.

\section{Sampel}

Sampel adalah sebagian dari jumlah dan karakteristik yang dimiliki oleh populasi dalm sebuah penelitian (Sugiyono, 2005). Metode pengambilan sampel yang digunakan dalam penelitian ini menggunakan teknik purposive sampling, yaitu dengan menentukan indikator-indikator spesifik sehubungan data dalam penelitian ini, dengan populasi yang telah ditentukan sebelumnya. Kriteria sampel dalam penelitian ini sebagai berikut :

1. Perusahaan manufaktur yang terdaftar di Bursa Efek Indonesia (BEI) untuk tahun 2014-2018

2. Perusahaan yang memiliki kepemilikan saham dari pihak asing

3. Perusahaan sampel tidak mengalami kerugian untuk periode pengamatan.

4. Menggunakan satuan mata uang rupiah

\section{Variabel Penelitian}

Transfer Pricing

Transfer pricing adalah kebijakan yang dilakukan oleh perusahaan dalam menentukan harga transfer dari setiap transaksi baik dari barang, jasa, harta tak berwujud, dan transaksi financial lainnya antara pihak yang mempunyai hubungan istimewa guna untuk memaksimalkan keuntungan perusahaan (Refgia, 2017). Pengukuran transfer pricing dalam penelitian ini adalah dengan menggunakan proksi rasio dari nilai transaksi pihak yang memiliki hubungan istimewa. Transfer dilakukan dengan perusahaan anak menjual produknya kepada induk perusahaan tanpa 
memperoleh keuntungan atau harga jual sama dengan harga pokok penjualan sehingga perusahaan akan seolah-olah merugi akibatnya perusahaan akan membayar pajak yang lebih sedikit.

\section{Pajak}

Menurut Mardiasmo (2016:1) pajak adalah iuran dari rakyat kepada kas negara berdasarkan undang-undang yang bersifat memaksa dengan tidak mendapat imbalan secara langsung diperoleh dan digunakan untuk membayar pengeluaran umum kepentingan negara. Sedangkan menurut UU No. 16 Tahun 2009 tentang Ketentuan Umum dan Tata Cara Perpajakan Pasal 1 ayat (1) : 8 pajak adalah setoran wajib bagi setiap warga negara kepada pemerintah baik oleh wajib pajak pribadi maupun wajib pajak badan yang bersifat memaksa yang mengacu pada undang- undang yang tidak memperoleh imbalan secara langsung tetapi pajak akan digunakan untuk keperluan negara dan kesejahteraan rakyat. Pengukuran pajak diukur dengan CETR adalah sebagai berikut:

$$
\mathrm{CETR}=\frac{\text { Kas Pajak }}{\text { Pendapatan Sebelum Pajak }}
$$

\section{Kepemilikan Asing}

Dalam Pasal 1 ayat 8 UU No. 25 Tahun 2007 menyebutkan bahwa modal asing adalah modal yang dimiliki oleh negara lain, perseorangan asing, dan Badan hukum Indonesia yang sebagian atau seluruh modalnya dimiliki oleh pihak asing. Dapat disimpulkan bahwa kepemilikan saham asing merupakan jumlah saham biasa perusahaan yang dimiliki oleh perorangan, badan hukum, pemerintah yang dimiliki oleh luar negeri (Anggraini, 2011). Pengukuran kepemilikan asing diukur adalah sebagai berikut:

$$
\text { Kep. Asing }=\frac{\text { Jumlah Kepemilikan Saham Terbesar }}{\text { Jumlah Saham Beredar }} \times 100
$$

\section{Bonus Plan}

Bonus plan adalah satu strategi atau motif perusahaan dengan menggunakan perhitungan akuntansi yang tujuannya untuk memberikan penghargaan kepada direksi atau manajemen dengan melihat laba secara keseluruhan selama tahun berjalann. Apabila penentuan pemberian bonus yang sudah tepat maka pemilik perusahaan menginginkan agar para direksi dapat meningkatkan kinerja perusahaan dengan cara meminimalkan beban pajak (Mispiyanti, 2015). Pengukuran bonus plan adalah dengan menggunakan (ITRENDLB) sebagai berikut:

$$
\text { Bonus Plan }=\frac{\text { Laba Bersih Tahun Berjalan }}{\text { Laba Bersih Tahun Sebelumnya }} \times 100 \%
$$

\section{Ukuran Perusahaan}

Ukuran perusahaan adalah besar atau kecilnya sebuah ukuran perusahaan tersebut. Untuk melihat jenis dari ukuran perusahaan yaitu dengan melihat jumlah asetnya apabila jumlahnya besar menunjukkan bahwa perusahaan tersebut telah mencapai tahap kedewasaan yang dilihat dari umur perusahaan yang mana arus kas perusahaan sudah bersifat positif dan dapat dianggap memiliki prospek baik dalam jangka waktu beberapa tahun kedepan. Ukuran perusahaan menjadi dasar investor dalam menanamkan modalnya karena akan berhubungan dengan resiko investasi yang dilakukan oleh para calon investor tersebut tersebut telah mencapai tahap kedewasaan dimana 
dalam tahap ini arus kas perusahaan sudah positif dan dianggap memiliki prospek yang baik dalam jangka waktu yang relatif lama. Pada umumnya penelitian di Indonesia menggunakan total aset sebagai proksi dari ukuran perusahaan. Ukuran perusahaan akan sangat penting bagi investor karena akan berhubungan dengan resiko investasi yang dilakukan (Pujiningsih, 2011). Pengukuran ukuran perusahaan menggunakan Ln total aset sebagai berikut:

$$
\text { SIZE }=\text { Ln Total Aset }
$$

\section{Model Analisis}

Penelitian ini dilakukan dengan menggunakan analisis regresi linier dengan Data tersebut diperoleh dari website www.idx.co.id kemudian data tersebut diolah dengan regresi data panel menggunakan software eviews 9. Bedasarkan data keuangan tersebut peneliti ingin menguji dan memberikan bukti empiris tentang pengaruh pajak, kepemilikan asing, bonus plan, dan ukuran perusahaan terhadap transfer pricing. Data yang digunakan dalam penelitian ini merupakan data sekunder yang mana berupa laporan keuangan perusahaan yang terdaftar di Bursa Efek Indonesia (BEI) pada tahun 2014-2018 secara berturut-turut.

$$
\mathrm{Y}=\alpha+\beta 1 \mathrm{X} 1+\beta 2 \mathrm{X} 2+\beta 3 \mathrm{X} 3+\beta 4 \mathrm{X} 4+\varepsilon
$$

Keterangan :

$\mathrm{Y}=$ Transfer Pricing

$\alpha=$ Konstanta

$\beta=$ Koefisien Variabel

$\mathrm{X} 1$ = Pajak

$\mathrm{X} 2=$ Kep. Asing

X3 = Bonus Plan

X4 = Uk Perusahaan

$\varepsilon=$ Error

\section{HASIL DAN PEMBAHASAN}

\subsection{Hasil Penelitian}

\section{Deskriptif Objek Penelitian}

Statistik deskriptif semua variabel dalam model disajikan dalam tabel berikut :

Tabel 1 Statistik Deskriftif

\begin{tabular}{lcccr}
\hline Keterangan & Minimum & Maximum & Mean & Std.Deviasi \\
\hline Pajak & 0,066277 & 1,520579 & 0,283630 & 0,143926 \\
Kep. Asing & 0,000583 & 0,995482 & 0,478400 & 0,260911 \\
Bonus Plan & 0,014456 & 53,72858 & 1,480538 & 4,181165 \\
Ukuran Perusahaan & 25,61948 & 33,47373 & 28,36703 & 1,593492 \\
Transfer pricing & 0,000000 & 0,999883 & 0,464752 & 0,386077 \\
\hline
\end{tabular}

Sumber : Data sekunder yang telah diolah, 2019

Berdasarkan hasil statistik deskritif tersebut diatas untuk variabel pajak memiliki nilai minimum sebesar 0,066277 dan nilai maximum sebesar 1,520579 dan memiliki nilai mean dan 
standar deviasi masing-masing 0,283630 dan 0,143926. Berdasarkan hasil statistik deskriftif tersebut diatas untuk variabel kepemilikan asing memiliki nilai minimum sebesar dan nilai maximum sebesar 0,000583 dan memiliki nilai mean dan standar deviasi masing-masing sebesar 0,478400 dan 0,260911. Berdasarkan hasil statistik deskriftif tersebut diatas untuk variabel bonus plan memiliki nilai minimum sebesar dan nilai maximum sebesar 0,014456 dan 53,72858 dan memiliki nilai mean dan standar deviasi masing-masing sebesar 1,480538 dan 4,181165 .

Berdasarkan hasil statistik deskriftif tersebut diatas untuk variabel ukuran perusahaan memiliki nilai minimum sebesar dan nilai maximum sebesar 25,61948 dan 33,47373 dan memiliki nilai mean dan standar deviasi masing-masing sebesar 28,36703 dan 1,593492. Berdasarkan hasil statistik deskriftif tersebut diatas untuk variabel Transfer pricing memiliki nilai minimum sebesar dan nilai maximum sebesar 0,000000 dan 0,999883 dan memiliki nilai mean dan standar deviasi masing-masing sebesar 0,464752 dan 0,386077.

\section{Analisis Regresi Data Panel}

Pengujian model estimasi maka model regresi yang sesuai untuk penelitian ini adalah random effect. Berikut ini adalah regresi data panel yang menggunakan model random effect:

\section{Tabel 2 Random Effect}

\begin{tabular}{lccc}
\hline \multicolumn{1}{c}{ Variable } & Coefficient & $t$-Statistic & Prob. \\
\hline C & 1,718729 & 1,888035 & 0,0608 \\
\hline Pajak & 0,250061 & 2,277444 & 0,0241 \\
Kep. Asing & 0,119334 & 0,801343 & 0,4241 \\
Bonus Plan & $-0,001203$ & $-0,350160$ & 0,5267 \\
\hline Uk. Perusahaan & $-0,048655$ & $-1,512521$ & 0,1324 \\
R-square & & & 0,047643 \\
Adjusted R-square & & & 0,023834 \\
F-statistic & & & 2,001064 \\
Prob (F-statistic) & & & 0,096884 \\
\hline
\end{tabular}

Sumber : Data sekunder yang telah diolah, 2019

Tabel 2 menunjukkan hasil regresi data panel dengan menggunakan random effect. Hasil regresi bertujuan untuk mengetahui adanya hubungan antara variabel independen (pajak, kepemilikan asing, bonus plan, dan ukuran perusahaan terhadap variabel dependen (transfer pricing).

\section{Uji Asumsi Klasik}

Setelah mengetahui model yang digunakan dalam penelitian kemudian menganalisis dan dilakukan pengujian asumsi klasik karena data yang akan dimasukkan dalam model regresi data harus memenuhi ketentuan dalam regresi data panel. Uji asumsi klasik terdapat 4 kategori yaitu uji normalitas, uji multikolinearitas, uji heteroskedastisitas, dan uji autokorelasi.

\section{Uji Multikolinearitas}

Uji multikolinearitas digunakan untuk menguji model regresi terhadap ditemukannya korelasi yang tinggi antar variabel independen. Menurut Ghozali (2013) cara untuk mendeteksi adanya tidaknya multikolinearitas adalah dengan matriks korelasi yaitu koefisien korelasi < 0,90 maka model bebas dari multikolineritas. Berikut ini disajikan hasil multikolinearitas: 
Tabel 3 Hasil Uji Multikolinearitas

\begin{tabular}{lcccc}
\hline Pajak & 1,000000 & 0,078235 & $-0,051445$ & $-0,100504$ \\
Kep. Asing & $-0,078235$ & 1,000000 & $-0,057735$ & 0,042496 \\
Bonus Plan & $-0,051445$ &,- 057735 & 1,000000 & $-0,012295$ \\
Uk. Perusahaan & $-0,100504$ & 0,042496 & $-0,012295$ & 1,000000 \\
\hline
\end{tabular}

Sumber : Data sekunder yang telah diolah, 2020

Berdasarkan tabel diatas diketahui bahwa nilai korelasi antar variabel independen kurang dari 0,90 $(<0,90)$, sehingga dapat disimpulkan bahwa tidak terjadi multikolinearitas.

\section{Uji Heteroskedastisitas}

Uji heteroskedastisitas dilakukan untuk mengetahui apakah dalam sebuah model regresi terjadi ketidaksamaan varians dari residual suatu pengamatan kepengamatan lain. Salah satu cara untuk mendeteksi adanya heteroskedastisitas yaitu jika nilai probabilitas dari masing-masing variabel > 0,05 maka dapat bahwa model tidak terdapat heteroskedastisitas, sebaliknya jika nilai probabilitas dari masing-masing variabel $<0,05$ maka model terjadi heteroskedastisitas.

Tabel 4 Hasil Uji Heteroskedastisitas

\begin{tabular}{lcccc}
\hline Variabel & Coefficient & Std. Error & t-Statistic & Prob. \\
\hline C & 0,180615 & 0,217528 & 0,830306 & 0,4134 \\
SER02 & $-0,069850$ & 0,117656 & $-0,593681$ & 0,5575 \\
SER03 & 0,071711 & 0,053257 & 1,346524 & 0,1889 \\
SER04 & 0,003112 & 0,011783 & 0,264122 & 0,7936 \\
SER05 & $-0,0044914$ & 0,006203 & $-0,792170$ & 0,4349 \\
\hline
\end{tabular}

Sumber : Data Sekunder yang telah dioleh, 2020

Berdasarkan tabel 4 dapat ditarik kesimpulan bahwa tidak terjadi heteroskedastisitas karena probabilitas lebih dari $0,05(<0,05)$.

\section{Uji Autokorelasi}

Uji autokrelasi bertujuan untuk apakah suatu model regresi linier ada korelasi antar kesalahan pengganggu pada periode $\mathrm{t}$ dengan kesalahan pada peride $\mathrm{t}-1$.

Tabel 5 Hasil Uji Autokorelasi

\begin{tabular}{llll}
\hline F-statistic & 1,149485 & Prob. F $(4,24)$ & 0,3575 \\
\hline Obs* R-squared & 5,305697 & $\begin{array}{l}\text { Prob. Chi-square } \\
(4)\end{array}$ & 0,2573 \\
\hline
\end{tabular}

Sumber: Data sekunder yang telah diolah, 2020

Berdasarkan nilai Prob Chi Square dengan uji Breusch-Godfrey Serial Correlation LM, yaitu sebesar 0,2573 dimana >0,05 sehingga tidak terjadi autokorelasi.

\section{Pengujian Hipotesis}

\section{Uji Statistik (Uji F)}


Uji statistik $\mathrm{F}$ digunakan untuk mengetahui apakah semua variabel independen yang dimasukkan dalam model mempunyai pengaruh secara bersama-sama (simultan) terhadap variabel dependen. Hal tersebut dapat dilakukan dengan membandingkan antara $\mathrm{F}$ dihitung dengan $\mathrm{F}$ tabel dan dengan nilai signifikansi kurang dari 0,05. Berdasarkan tabel 2 diatas, diketahui nilai $\mathrm{F}$ hitung sebesar 2,001064 dengan probabilitas sebesar 0,096884. Probabilitas lebih besar dari 0,05 sehingga dapat simpulkan bahwa pajak, kepemilikan asing, bonus plan, dan ukuran perusahaan secara simultan tidak berpengaruh terhadap transfer pricing.

\section{Uji Hipotesis (Uji t)}

Uji t digunakan untuk mengetahui tingkat signifikansi pengaruh masing-masing variabel independen yaitu pajak, kepemilikan asing, bonus plan, dan ukuran perusahaan terhadap variabel dependen yaitu transfer pricing. Kriteria pengujian adalah jika prob $>\alpha=0,05$ maka Ho diterima yang berati variabel independen ke-I tidak memiliki pengaruh. Sebaliknya jika prob $<\alpha 0,05$ maka Ho ditolak yang berati variabel independen ke-I memiliki pengaruh signifikan. Berikut ini disajikan hasil uji hipotesis:

\begin{tabular}{lccc} 
& & Tabel 6 Hasil Uji Hipotesis \\
\hline \multicolumn{1}{c}{ Variabel } & t-statistic & Signifikan & Keterangan \\
\hline Pajak & 2,277444 & 0,0241 & Signifikan \\
Kep. Asing & 0,801343 & 0,4241 & Tidak Signifikan \\
Bonus Plan & $-0,350160$ & 0,5267 & Tidak Signifikan \\
Uk. Perusahaan & $-1,512521$ & & Tidak Signifikan \\
\hline
\end{tabular}

Sumber: Data sekunder yang telah diolah, 2019

Tabel 6 menunjukkan hasil probabilitas signifikansi pada masing-masing variabel independen yang dijelaskan sebagai berikut :

a. Pajak

Pajak memiliki t statistik sebesar 2,277444 dengan nilai signifikansi 0,0241. Hal ini menunjukkan bahwa nilai signifikansi lebih kecil dari 0,05 yang berati pajak berpengaruh terhadap transfer pricing, maka Ho ditolak (hipotesis 1 diterima).

b. Kepemilikan Asing

Kepemilikan asing memiliki t statsitik sebesar 0,801343 dengan nilai signifikansi 0.4241 . Hal ini menunjukkan bahwa nilai signifikansi lebih besar dari 0,05 yang berati kepemilikan asing tidak berpengaruh terhadap transfer pricing, maka Ho diterima (hipotesis 2 ditolak).

c. Bonus plan

Bonus plan memiliki t statistik sebesar $-0,350160$ dengan nilai signifikansi 0,5267 . Hal ini menunjukkan bahwa nilai signifikansi lebih besar dari 0,05 yang berati bonus plan tidak berpengaruh terhadap transfer pricing, maka Ho diterima (hipotesis 3 ditolak).

d. Ukuran perusahaan 
Ukuran perusahaan memiliki t statistik sebesar -1,512521 dengan nilai signifikansi 0,1324 . Hal ini menunjukkan bahwa nilai signifikansi lebih besar dari 0,05 yang berati ukuran perusahaan tidak berpengaruh terhadap transfer pricing, maka Ho diterima (hipotesis 4 ditolak).

\subsection{Pembahasan}

\section{Pengaruh Pajak Terhadap Transfer Pricing}

Adanya perbedaan informasi yang terjadi antara pemegang saham dan pihak manajemen dapat memberi kebebasan bagi manajemen untuk melaksanakan kegiatan yang tidak seluruhnya diketahui oleh pemegang saham. Dalam hal ini, manajemen memanfaatkan celah peraturan perpajakan antar negara yang berbeda untuk melakukan praktek transfer pricing untuk menurunkan beban pajak, semakin tinggi beban pajak perusahaan semakin mendorong perusahaan melakukan transfer pricing. Hasil regresi menunjukkan bahwa ditemukannya pengaruh positif yang signifikan dari pajak terhadap transfer pricing. Hasil penelitian ini sejalan dengan penelitian yang dilakukan oleh Tiwa et al. (2017), Yuniasih et al. (2012), Kiswanto et al, (2014), Hartati dan Azlina (2014) yang menyatakan bahwa pajak berpengaruh positif terhadap transfer pricing.

\section{Pengaruh Kepemilikan Asing Terhadap Transfer Pricing}

Perusahaan melakukan transfer pricing adalah kesepakatan dari direksi perusahaan dan akan melakukan transfer pricing untuk memaksimalkan kesejahteraan pribadi. Persentase kepemilikan saham oleh asing yang cukup besar belum tentu dapat membuat pemegang saham asing pada posisi yang kuat untuk mengendalikan perusahaan termasuk mempengaruhi keputusan perusahaan untuk melakukan praktik transfer pricing. Karena perusahaan melakukan transfer pricing atas kesepakatan direksi bukan dari investor yang memiliki saham asing dapat menentukan perusahaan melakukan transfer pricing dikarenakan investor tidak mengetahui informasi yang mendetail mengenai perusahaan seperti contoh: sistem informasi manajemen, kegiatan operasional perusahaan. Jadi besar kecilnya kepemilikan asing tidak mempengaruhi perusahaan melakukan transfer pricing.

Hasil pengujian menunjukkan bahwa variabel kepemilikan asing mempunyai nilai koefisien sebesar 0,119334 dengan nilai signifikansi sebesar 0,4241. Nilai sign probabilitas dari kepemilikan asing lebih besar dari 0,05 (>0,05) maka kepemilikan asing tidak berpengaruh terhadap transfer pricing. Dengan demikian, hipotesis yang telah dirumuskan $(\mathrm{H} 2)$ ditolak. Sehingga dapat dikatakan bahwa kepemilikan asing tidak berpengaruh terhadap transfer pricing. Hasil penelitian ini sesuai dengan penelitian yang dilakukan oleh Tiwa et al. (2017) dan Nurjanah et al. (2015) yang menunjukkan bahwa kepemilikan asing tidak berpengaruh terhadap keputusan transfer pricing.

\section{Pengaruh Bonus Plan Terhadap Transfer Pricing}

Keputusan perusahaan melakukan transfer pricing atas kesepakatan dari direksi perusahaan maka untuk memaksimalkan kesejahteraan pribadi. Bonus tidak berpengaruh terhadap transfer pricing dikarenakan perusahaan akan memberikan bonus atas laba yang telah dicapai oleh perusahaan karenanya tidak didasarkan oleh tinggi rendahnya bonus plan yang diberikan perusahaan karena sesuai dengan bonus hypotesis apabila perusahaan mengalami laba maka akan tetap memberikan bonus terhadap para direksi atas kinerjanya terhadap perusahaan. Maka dari itu kendali dari diri sendiri (internal) dengan memiliki sikap jujur sehingga para direksi tidak akan menaikkan laba hanya dengan tujuan agar memperoleh bonus yang lebih tinggi sehingga para 
direksi tidak memiliki motivasi untuk melakukan transfer pricing karena dengan perusahaan laba maka sudah menunjukkan kinerja yang baik..

Hasil pengujian menunjukkan bahwa variabel bonus plan mempunyai nilai koefisien sebesar $-0,001203$ dengan nilai signifikansi sebesar 0,5267. Nilai sign probabilitas dari bonus plan lebih besar dari 0,05 $(>0,05)$ maka bonus plan tidak berpengaruh terhadap transfer pricing. Maka hipotesis yang telah dirumuskan (H3) ditolak. Sehingga dapat dikatakan bahwa bonus plan tidak berpengaruh terhadap transfer pricing. Hasil penelitian ini sejalan dengan penelitian yang dilakukan oleh Mispiyanti (2015), Hartati dan Azlina (2014), dan Rosa et al. (2017) menyatakan bahwa bonus plan tidak berpengaruh terhadap keputusan transfer pricing.

\section{Pengaruh Ukuran Perusahaan Terhadap Transfe Pricing}

Besar kecilnya ukuran perusahaan tidak berpengaruh terhadap transfer pricing, hal ini dikarenakan apabila suatu perusahaan memiliki tujuan untuk melakukan transnfer pricing maka akan melakukan transnfer pricing karenanya bukan dilihat dari besar kecil ukuran suatu perusahan melainkan tujuan dari perusahaan itu sendiri apakah memiliki tujuan melakukan transfer pricing atau tidak. Karenanya apabila perusahaan memiliki tujuan untuk melakukan transfer pricing akan melakukan nya tanpa melihat dari besar kecil ukuran suatu perusahaan dan juga perusahaan akan melihat kemampuan perusahaan apakah mampu melakukan transfer pricing atau tidak dengan memiliki staff ahli yang ditempatkan untuk perusahaan melakukan transfer pricing.

Hasil pengujian menunjukkan bahwa variabel ukuran perusahaan mempunyai koefisien sebesar -0,048655 dengan nilai signifikansi sebesar 0,1324. Nilai sign probabilitas dari ukuran perusahaan lebih besar dari 0,05 $(>0,05)$ maka ukuran perusahaan tidak berpengaruh terhadap transfer pricing. Dengan demikian, hipotesis yang telah dirumuskan (H4) ditolak. Sehingga dapat dikatakan bahwa ukuran perusahaan tidak berpengaruh terhadap transfer pricing. Hasil penelitian ini sejalan dengan penelitian yang dilakukan oleh Akbar (2015) dan Refgia (2017) yang menyatakan bahwa ukuran perusahaan tidak berpengaruh terhadap transfer pricing.

\section{KESIMPULAN dan SARAN Kesimpulan} berikut :

Berdasarkan analisis data yang telah dilakukan, maka dapat diambil kesimpulan sebagai

a. Pajak berpengaruh positif terhadap transfer pricing pada perusahaan manufaktur yang terdaftar di Bursa Efek Indonesia (BEI) pada tahun 2014-2018.

b. Kepemilikan asing tidak berpengaruh terhadap transfer pricing pada perusahaan manufaktur yang terdaftar di Bursa Efek Indonesia (BEI) pada tahun 2014-2018.

c. Bonus plan tidak berpengaruh terhadap transfer pricing pada perusahaan manufaktur yang terdaftar di Bursa Efek Indonesia (BEI) pada tahun 2014-2018.

d. Ukuran perusahaan tidak berpengaruh terhadap transfer pricing pada perusahaan manufaktur yang terdaftar di Bursa Efek Indonesia (BEI) pada tahun 2014-2018.

Berdasarkan hasil penelitian yang dibahas pada bab sebelumnya, maka keterbatasan dalam penelitian ini adalah Nilai koefisien determinasi dalam penelitian ini maish relatif kecil yaitu sebesar 0,023834 yang menunjukkan variabel pajak, bonus plan, kepemilikan asing, dan ukuran perusahaan hanya mampu mempengaruhi keputusan perusahaan untuk melakukan transfer pricing sebesar 2,38\% yang artinya masih terdapat variabel lain di luar penelitian sebesar 97,62\% yang dapat mempengaruhi variabel yang diteliti. 


\section{Saran}

Proksi yang digunakan dalam pengukuran transfer pricing pada penelitian ini terbatas dengan ada atau tidaknya penjualan dengan pihak yang memiliki hubungan istimewa. Penelitian selanjutnya diharapkan dapat menggunakan proksi lain jika datanya dimungkinkan untuk tersedia, seperti dalam bentuk rasio.

\section{DAFTAR PUSTAKA}

Anggraini, R.D, 2011, Pengaruh Kepemilikan Institusional dan Kepemilikan Asing Terhadap Pengungkapan Pertanggung Jawaban Sosial Perusahaan Dalam Annual Report, Skripsi, diakses dari http://eprints.undip.ac.id

Dynaty, Vera, Sidharta U, Hilda R dan Sylvia V, 2011, Pengaruh Kepemilikan Pengendali Akhir Terhadap Transaksi Pihak Berelasi, Skripsi, diakses dari http://journal.ac.id

Ghozali, Imam, 2013, Aplikasi Analisis Multivariat dengan Program IBM SPSS 21. Edisi 7. Penerbit Universitas Diponegoro. Semarang

Hartanti, W., Desmiyawati, \& Julita. 2015. Tax Minimization, Tunneling Incentive dan Mekanisme Bonus terhadap Keputusan Transfer Pricing Seluruh Perusahaan yang Listing di Bursa Efek Indonesia. Simposium Nasional Akuntansi 18, 16 - 19.

Hartati, W. dan Azlina, D. 2014. Analisis Pengaruh Pajak Dan Mekanisme Bonus Terhadap Keputusan Transfer Pricing (Studi Empiris Pada Seluruh Perusahaan Yang Listing Di Bursa Efek Indonesia). SNA 17 Mataram. Universitas Mataram. September 2014

https://ekonomi.bisnis.com/read/20190918/259/1149724/oecd-kasus-transfer-pricing-meningkat

Jensen, M. and W.H. Meckling, 1976. Theory of the Firm: Magerial Behavior. Agency Cost and Ownership Structure. Journal of Financial Economics. 03. 305-36

Kharisma, 2014. Pengaruh Pajak, Tunneling Incetive dan Kompensasi Bonus Terhadap Keputusan Transfer Pricing (Study Empiris Pada Perusahaan Manufaktur yang Listing di BEI Tahun 2010-2012). Skripsi. Universitas Mercu Buana

Kiswanto, Nancy dan Anna P, 2013, Pengaruh pajak, Kepemilikan Asing, dan Ukuran Perusahaan Terhadap Transfer Pricing pada Perusahaan Manufaktur di BEI Tahun 2010-2013, dari www.e-journal.uajy.ac.id

Lamria, Margaretha. 2012. Analisis Ketentuan tentang Prinip Kewajaran Atas Transaksi Penjualan Penjualan Antar Wajib Pajak yang Mempunyai Hubungan Istimewa Di Indonesia. Skripsi. Universitas Indonesia

Mardiasmo. 2016. Perpajakan Edisi Revisi. Edisi 18. Penerbit Andi. Yogyakarta

Mispiyanti, 2015, Pengaruh Pajak, Tunnelling Insentive dan Mekanisme Bonus Terhadap Keputusan Transfer Pricing, Jurnal Akuntansi dan Investasi, dari www.journal.umy.ac.id, 16.63-70 
Nurjanah I, Isnawati, dan Antonius G. 2015. Faktor Determinan Keputusan Perusahaan Melakukan Transfer Pricing. Universitas Lambung Mangkurat. Full PaperJurnal

Pujiningsih, A.I. 2011. Pengaruh Struktur Kepemilikan, Ukuran Perusahaan, Praktik Corporate Governance dan Kompensasi Bonus terhadap Manajemen Laba (Studi Empiris Pada Perusahaan Manufaktur yang Terdaftar di BEI Periode 2007-2009). Skripsi. Fakultas Ekonomi Universitas Diponegoro

Refgia, Thesa. 2017. Pengaruh Pajak, Mekanisme Bonus, Ukuran Perusahaan, Kepemilikan Asing dan Tunneling Incentive Terhadap Transfer Pricing (Perusahaan Sektor Industri Dasar dan Kimia Yang Listing di BEI Tahun 20112014). Universitas Riau, Pekanbaru Riau. JOM Fekon Vol. 4 No. 1 dari www.jom.unri.ac.id

Supriyanto, dan F., Falikhatun. 2008. Pengaruh Tangibility Pertumbuhan dan Ukuran Perusahaan terhadap Stuktur Keuangan. Jurnal Bisnis dan Akuntansi 10

Taylor, Richardson, G 2013, Determinants Of Transfer Pricing Aggressivinesss : Empirical Evidence From Australian Firms, www.sciencedirect.com

Thomas, 2019. Dugaan Adaro Menghindari Pajak Mengingatkan Pada Kasus Asian Agri. 6 Juli. Http://tirto.id//dugaan-adaro-menghindari-pajak-mengingatkan-pada-kasus-asisan-agri

Undang-Undang Republik Indonesia No.16 Tahun 2009 tentang Ketentuan Umum dan Tata Cara Perpajakan Pasal 1 ayat 1

Undang-Undang No.25 pasal 1 ayat 8 Tahun 2007 menyebutkan bahwa Modal Asing

Wijaya, Darma Sudata, Supatmi dan Yeterina Widi. 2009. Struktur Kepemilikan. Ukuran Perusahaan dan Related Party Transaction, Skripsi

Yuniasih, N. W., N. K. Rasmini, dan M. G. Wirakusuma. 2012. Pengaruh pajak dan tunneling incentive pada keputusan transfer pricing perusahaan Manufaktur yang listing di bursa efek indonesia. Simposium Nasional Akuntansi 15 
Dyah Detari Prabaningrum, Titiek Puji Astuti, Yunus Harjito / Edunomika Vol. 05, No. 01 (2021) 